\title{
ORANGE PEEL AND JAVA SUGAR AS AN ALTERNATIVE TO NATURAL DISINFECTANT IN COVID-19 PREVENTION EFFORTS IN THE TOBACCO FARMING AREA, COASTAL AREA, JEMBER DISTRICT
}

\author{
Ibnu Mubarok ${ }^{1}$, Astika Shiella Nabila Putri ${ }^{2}$, Clarrisa Ayu Candra Kirana ${ }^{3}$, Kristanti \\ Wahyuningtiyas ${ }^{4}$, Mury Ririanty ${ }^{5}$, Nabila Zandra Kartika ${ }^{6}$, and Rofiah Adawiyah Wisudawati \\ Ning Tias $^{7}$ \\ ${ }^{1}$ Faculty of Public Health, Jember University, Indonesia \\ 1'Ibnumubarok7780@gmail.com, 22astikashiella28@ gmail.com, ${ }^{3}$ acekaclarissa@ gmail.com, \\ kㅏistatntiwahyuningtiyas@gmail.com, ${ }^{5}$ muryririanty@yahoo.com, ${ }^{6}$ nabilazandra16@ gmail.com, \\ ovikias@gmail.com
}

\begin{abstract}
Jember regency is one of those with a thriving agricultural sector. The main commodity produced by the agricultural sector of the tobacco district of Jember. However, the communities in the tobacco farming region tend to lack a knowledge level especially in the COVID-19 case. This made the farmer less able to share about COVID-19 with their children who were the generation of nations, so that the children's knowledge of the farmer became inferior. In the time of new adaptation habits, communities needed a COVID-19 preventive and countermeasure measure by periodic self-infection. Because of restrictions on the use of chemical disinfectant, researchers replaced it with natural ingredients for the peel of an orange and sugar from Java. The purpose of this research is empowering societies to increase awareness, will and ability in raising degrees of health by educating children early in life so that they can benefit themselves, their families, and their environment. The methods used in this research are descriptive research with a qualitative approach. The results obtained from this study are an increased audiens knowledge and skill in the making of natural disinfectant as one of the COVID19 prevention efforts.
\end{abstract}

Keyword: Children, COVID-19, knowledge, prevent, disinfectant

\section{Introduction}

The conditions of coronavirus diseases (SARS-COV-2), commonly called covid-19, are now of global concern. On January 30, 2020, the World Health Organization (WHO) has established the case of coronavirus diseases as public health emergency of international concern (PHEIC) in which it causes extremely complex problems from a health concern to paralyses social economic conditions [1]. The COVID-19 case in the region of east Java occupied the second highest case in Indonesia [2]. Jember Regency is one of the areas that has contributed to the high number of COVID-19 cases in East Java, with a total of 554 cases as of September 3, 2020 [3].

Jember Regency is one of those with a thriving agricultural sector [4]. Among the main commodities produced by the agricultural sector of jember district was tobacco. Therefore agriculture is known as the dominant sector in this region. But on the other hand, the average levels of community knowledge in the agricultural region tend to lack particularly knowledge about COVID-19 as a result of the limited education requirement and the optimal use of technology. The lack of public knowledge led to a reduced education given by parents to children associated with COVID-19. As for dealing with the COVID-19 pandemic conditions, it requires precise prevention and countermeasures to achieve better degrees of health. Even more so in new adaptations such as today, prevention and countermeasures must be done in an extra way by involving the entire population of the age group, including children as a realistic response to the existence of COVID-19.

One of the notable prevention of transmission of the covid-19 was during a new 
custom of adaptation is to carry out regular independent disinfection [5]. Disinfectant is generally a blend of some chemicals. This causes the use of disinfectant to be limited, especially domestic use because the qualities and effects it gives can be harmful to the body and the environment [5]. As an alternative to the presence of chemicals used in disinfectant solution, orange peels and sugar java can become a natural compound for disinfectant [6]. The use of natural materials can also reduce the weight of the final dump (landfill), where $70 \%$ of waste on landfills is dominated by organic garbage [7].

Based on the issues outlined, researchers would like to provide a related education of use and natural disinfectant as a preventive and community-based covid-19 prevention and countermeasure measure for people's empowerment to increase awareness, will and ability in improved health degrees. Empowerment of early education for children so that they can benefit themselves, their families, and their environment. According to Jean Piaget, improving children's thinking ability through the process of active learning can involve actively optimizing activities for all of children's senses [8]. Moreover, empowerment in this child is expected to be able to develop children independently and proactively in covid-19 prevention and countermeasure efforts.

\section{Methods}

This research is a descriptive research with a qualitative approach. Descriptive research is research that intends to describe the phenomenon in education and the manufacture of natural-based disinfectants using orange peels and sugar java. The study employs a qualitative research approach because researchers want to delve deeply into information through a descriptive data of speech or writing and observable behavior on the study subject.

The population and research sample were children of tobacco farmers and laborers aged 4-12 years in Bagon and Jambearum Villages, Puger District, Jember Regency.

\section{Result}

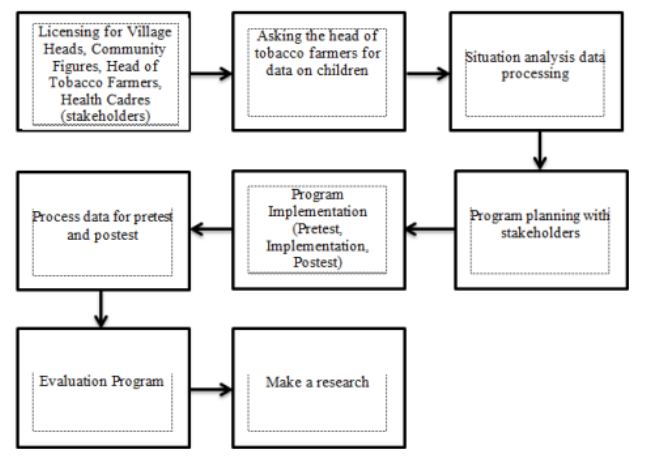

Figure 1. Flow of Research Implementation

Before giving education about one of the efforts to prevent the spread of the corona virus, namely disinfection, the audience still showed confused expressions when asked questions about the definition of disinfection. Silence and staring at each other as if to describe their ignorance. In fact, most of them admit that they have never heard the word disinfection.

But after little by little an explanation has been given about the definition of disinfection, the benefits of disinfection, what kinds of surfaces to disinfect, and the frequency of disinfectant in a day, the head nods begin to appear indicating they understood what was being explained. In addition, it is also explained that a disinfectant can be made independently in the home using only two ingredients - orange peels and sugar java and what makes both of these ingredients possible for a disinfectant. Even when asked a question and asked to explain again, they are able to make a suitable reply. For example when asked questions about the definitions and benefits of disinfection, their answers vary and remain within the same core.

"Spraying the surface of objects so the virus can die."-IU1, 5 years old

"Activities that kill the virus to keep it from the corona virus."-IU2, 9 years old

"Kill a virus that will harm mankind and keep it from the corona virus." IU3, 9 years old

Likewise, other questions can be answered easily by them. Enthusiastic Shouting was especially heard as they were 
invited to create a natural disinfectant made from orange peels and sugar java. The plastic bottles they had brought with them as vials of disinfectant had not gone unnoticed. After instruction, they deftly applied the production of a natural disinfectant from orange peels and sugar java.

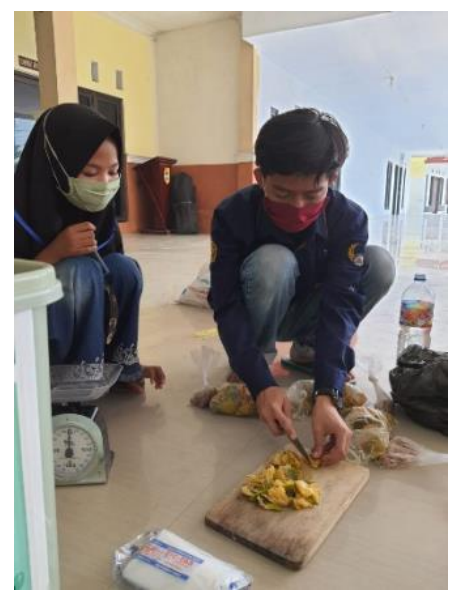

Figure 2. Cutting orange peels for disinfectant in Bagon Village

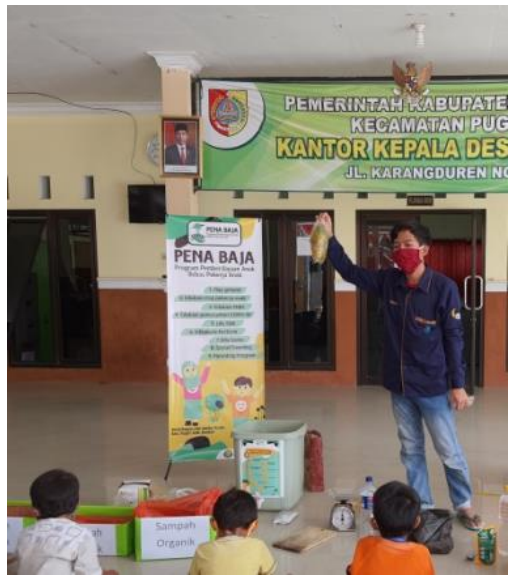

Figure 3. Enthusiastic children of tobacco farmer's in paying attention to the facilitators Bagon Village

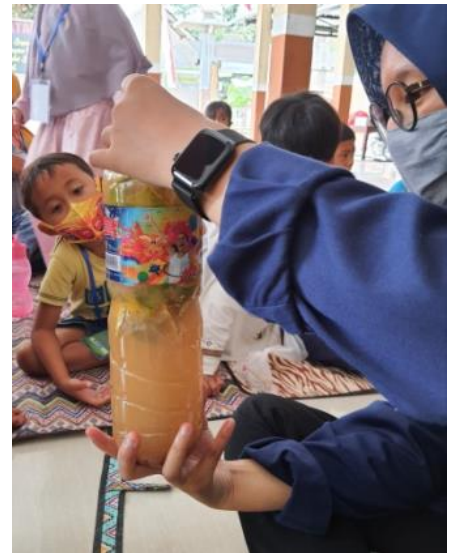

Figure 4. Natural disifectant manufacturing product

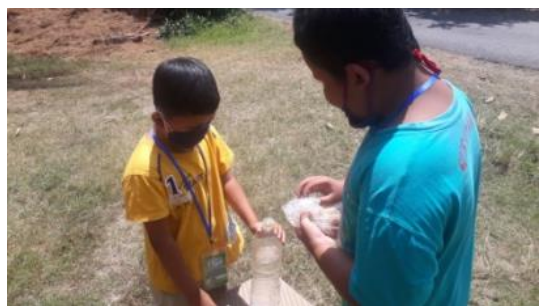

Figure 5. Prepare tools and materials for making natural disinfectant in Jambearum Village

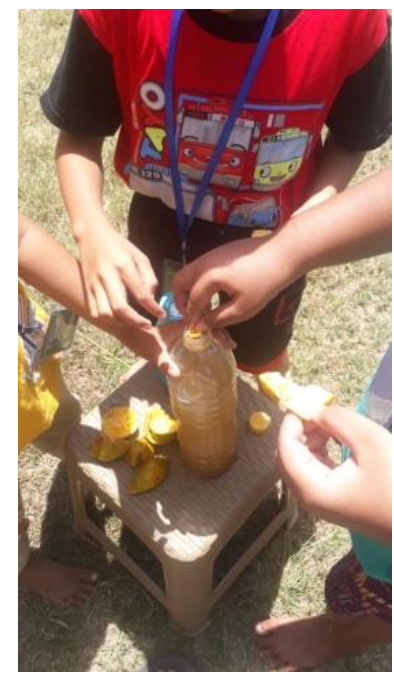

Figure 6. The process of making natural disinfectant in Jambearum Village 


\section{Discussion}

\subsection{Knowledge and skill}

The increased knowledge and skill of the audiens in the making of a natural disinfectant as one of the covid-19 prevention efforts became an indicator of the program's success. It can be seen that participants' knowledge of disinfection increased. The bewildered look on their faces turned into enthusiastic facial expressions and nodded at them as they understood the explanation. Furthermore, answering the appropriate questions also indicates that there is an increased knowledge in the audience.

The domain of one's behavior is distinguished into the three domain of behavior which is knowledge, attitude, and action. Knowledge is a result of human sensing of an object so that one eventually comes to know and understand about it, and is able to articulate, analyze, synthesize, and evaluate the objects he already knows [9].

Furthermore, with its practising of the natural disinfectant, it can be said that the attitude shown by the audiences has already manifested itself in action. An attitude can be defined as a person's closed response to something and a tendency to act. As a result of this action, the raw materials of orange peels and sugar java are also beginning to increase.

\subsection{Method of Implementation}

1. Tools and materials
a) Mineral water bottle (1.5 liter)
b) Knife
c) cutting board
d) Java sugar (100 grams)
e) Orange peel (3 ounces)
f) Water (1 liter)

2. How to manufacture

This disinfectant is made up of orange peel, water, sugar. Its manufacture requires a plastic container in the manufacture of a mineral water bottle, the use of a glass material is largely avoided because it can cause a burst in the flow of fermentation microbial activity. The manufacturing method was to add a pint of water to the bottled mineral water. Then add one hundred grams of sugar (Java sugar) and stick a small slice of orange peel with a knife and a mull (3 ounces). Afterward cover the bottled water used for 3 months and open daily to release gas so that it will not explode for the day 7 , day 30 and day $90 \mathrm{se}$. To avoid contamination, place containers where they are exposed to direct sunlight, good circulation of air, away from wifi, toilets, trash cans, dustbins, and chemicals. Briefly the production of this disinfectant is described as follows:

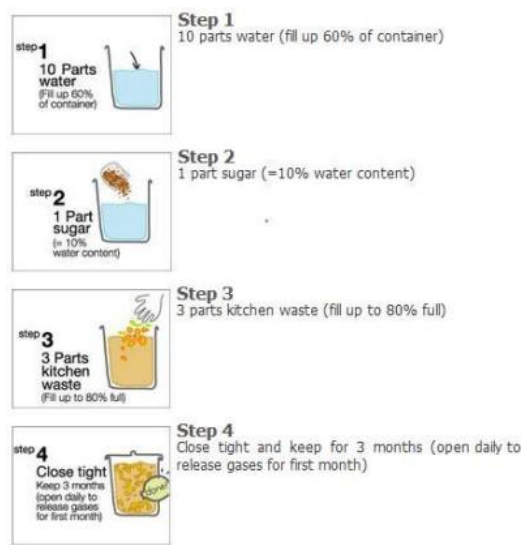

Figure 2. Steps on making disinfectant

source: www.waystosaveenergy.net

After 90 days, this disinfectant is ready to be harvested by way of the filter and stored in a sealed container. In this disinfectant solution it has no expiration date. The production of this disinfectant is very simple and makes use of the simple materials that surround us so that everyone can make them. It has the potential to be produced on a variety of scales, not only on a large scale, but also on a small scale in the home. Hence, the product is highly prospecting to be produced on a wide range, including a small scale in a community base.

\subsection{Content of Orange Peels}

The high vitamin c content of oranges has good benefits for body health. Not just vitamin c, oranges contain levels of vitamin b1, b2, b3, b6, and b9, which are highly healthful. It also has important mineral deposits such as magnesium, iron, phosphorus, calcium, potassium, selenium and zinc. After eating an orange, most people would discard the peel. Little did anyone know that the peel had more fitonutrien and flavonoid than the flesh-pulp of the orange. As professor irmanida coal said, professor of the Institut Pertanian Bogor (IPB), also head of the biofarthen tropika (tropbrc), that compounds that are said to provide protection against 
microbes and viruses. The compound is a flavonoid class [10]. Flavonoids (flavus, the Latin word for yellow) or bioflavonoids, polyphenolic low weight secondary metabolites, are present in great number of higher plant species, principally placed in fruit bark, seeds or flowers [11]. Flavonoids have several compounds, one of them which is hesperidin. The hesperidin is said to provide protection against microbes and viruses. Numerous studies confirmed a potent bioactivity of Hesp, such as effects on the vascular system (reduces capillary permeability), anti-inflammatory effects, antioxidant effect, action on enzymes, antimicrobial activity (antibacterial, antifungal, antiviral, anticarcinogenic activity, cell aggregation inhibition, antiallergic effects, UV protecting activity, radioprotection, and so on. In the further text, more specific information about Hesp effects on the cardiovascular system are given. Also, the literature describing Hesp as promising protector against ionizing radiation is assembled [11]. Hence, the peel has many health benefits such as the prevention of covid-19 disease.

\subsection{Content of sugar java}

In Java sugar has high levels of such compounds as thiamins/vitamin b1, riblofavin, niketinat acid, ascorbic acid, protein and vitamin $c$ [12]. In the production of this disinfectant compound in Java it causes fermentation because it provides nutrition to the microorganisms that distill the anaerobic process takes place. The nutritional value of this disinfectant is due to the presence of alcohol and/or acetate acid found in the liquid. Alcohol and/or acetic acid are produced from a bacterial metabolic process that is naturally found in the peel of an orange. The process of anaerobic metabolism, also called fermentation, is a bacterial effort to achieve energy from carbohydrates in anaerobic (nonoxygen) conditions and byproduct (byproduct) of alcohol or acetate acid (dependent on a type of microorganisms). Funguses and certain types of bacteria produce alcohol in the fermentation process, while most bacteria produce acetic acid. This process of fermentation results from the enzyme activity contained in bacteria or fungi [13]. Alcohol is a chemical that can be produced from starch, sugar, and lignocellulose plants. Alcohol produced from this fermentation is commonly called bioethanol. In general ethanol/bioethanol can be used as a raw material in the pharmaceutical industry, as an antiseptic, as a preservative, a solvent and a fuel compound for vehicles (sugar palm) [14].

4.5 Measures to use

Table 1. Measures to use

\begin{tabular}{lcc}
\hline \multicolumn{1}{c}{ Usage } & \multicolumn{2}{c}{ Comparison } \\
\cline { 2 - 3 } & $\begin{array}{l}\text { Disinfectant } \\
\text { Solution }\end{array}$ & Water \\
\hline $\begin{array}{l}\text { Wash the dishes } \\
\text { (can be mixed with a }\end{array}$ & $1 \mathrm{ml}$ & $10 \mathrm{ml}$ \\
little liquid dish soap & & \\
to make it foamy) & & \\
Air freshener & $1 \mathrm{ml}$ & $200 \mathrm{ml}$ \\
Watering the plants & $1 \mathrm{ml}$ & $500 \mathrm{ml}$ \\
Disinfectant & $1 \mathrm{ml}$ & $500 \mathrm{ml}$ \\
Mopping the floor & $1 \mathrm{ml}$ & $100 \mathrm{ml}$ \\
\hline
\end{tabular}

\section{Conclusion}

Based on the results of the research that has been carried out, it can be concluded that there is an increase in the knowledge and skills of the audience in making natural disinfectants as an effort to prevent the spread of COVID-19. This was evidenced by the change in expression when the researcher asked intermezzo briefly about disinfection from initially silent and confused to knowing by answering the questions given by the researcher after the researcher provided material about self-disinfection appropriately.

\section{References}

[1] World Health Organization (WHO). 2020 "COVID-19: Public Health Emergency of International Concern (PHEIC)" published in who.int.

[2] Gugus Tugas Percepatan Penanganan COVID-19. 2020 "Data Harian Kasus Per Provinsi COVID-19 Indonesia" published in bnpb-inacovid19.hub.arcgis.com.

[3] Pemerintah Kabupaten Jember. 2020 "Data Pantauan dan Peta Sebaran COVID-19 di Kabupaten Jember" published in Instagram pemkabjember. 
[4] F. H. Putra, H. M. Ani, W. Hartanto, 2018 "Kontribusi Sektor Pertanian Terhadap PDRB Kabupaten Jember Tahun 20122016," in Jurnal Pendidikan Ekonomi: Jurnal Ilmiah Ilmu Pendidikan, Ilmu Ekonomi, dan Ilmu Sosial, vol. 12 No.1, pp. 71-74

[5] World Health Organization (WHO), 2020 "Pembersihan dan Disinfeksi Permukaan Lingkungan dalam Konteks COVID-19" published in who.int.

[6] B. Dwi. M, Desmintari, Yuhanijaya, 2017 "Pemberdayaan Masyarakat Desa Citeras Rangkasbitung Melalui Pengolahan Sampah Dengan Konsep Eco-Enzyme dan Produk Kreatif yang Bernilai Ekonomi." In Prosiding Seminar Nasional Pengabdian Kepada Masyarakat, vol. 2 No. 1, pp. 1-6.

[7] Buleleng.kab, 2020 "Modul Belajar Pembuatan Eco-Enzyme 2020," published in bulelengkab.go.id

[8] F. Ibda, 2015 "Perkembangan Kognitif: Teori Jean Piaget" in Jurnal UIN ArRaniry, vol. 3 No. 1, pp. 27-38 published in jurnal.ar-raniry.ac.id.

[9] Rokhmah, dkk, 2019 "Penelitian Kualitatif Bidang Kesehatan Masyarakat” Malang: Intimedia.

[10] Yuwono, T., 2020 “ Senyawa Dalam Kulit Jeruk Bermanfaat Melawan Virus Corona (Covid-19)" Retrieved September 4, 2020, from Businessinsight: https://insight.kontan.co.id/news/senyawa -dalam-kulit-jeruk-bermanfaat-melawanvirus-corona-covid-19

[11] Kuntic Vesma, et al, 2014 "Evaluating the bioactive effects of flavonoid hesperidin - A new". Vojnosanit Pregl, 60-65.

[12] Garjito, M., 2012 "Bumbu, Penyedap, dan Penyerta Masakan Indonesia" Jakarta: Gramedia Pustaka Utama.

[13] Syaravina, S., 2018 "Eco-Enzyme: Multipurpose Liquid from Organic Waste" Retrieved September 4, 2020, from wastechange: https://waste4change.com/eco-enzymemultipurpose-liquid-from-organicwaste/2/

[14] Putri, W. T, 2012 "Potensi Nira Aren (Arenga pinnata) Sebagai Bahan Baku Bioetanol" Jurnal Riset Industri Hasil Hutan, 6-10. 